\title{
Elementary School Students Understanding of Environmental Concepts in the City of Surabaya
}

\author{
Rindawati* \\ Geography Education Department \\ Faculty of Social Sciences and Law, \\ Universitas Negeri Surabaya \\ Surabaya, East Java, Indonesia \\ rindawati@unesa.ac.id
}

\author{
Sulistinah \\ Geography Education Department \\ Faculty of Social Sciences and Law, \\ Universitas Negeri Surabaya \\ Surabaya, East Java, Indonesia \\ sulistinah@unesa.ac.id
}

\author{
Bambang Sigit Widodo \\ Geography Education Department \\ Faculty of Social Sciences and Law \\ Universitas Negeri Surabaya \\ Surabaya, East Java, Indonesia \\ bambangsigit@unesa.ac.id
}

\begin{abstract}
Increasing population is not matched by an understanding of the environment would result in destruction of the environment. Therefore, education about the environment is indispensable. This study aims 1) To find out how the understanding of elementary school students in the city of Surabaya on the environment; 2) To know of whom gained an understanding of the environment and of any subjects. The population in this study were students of class $V$ Elementary School in Surabaya. Samples were taken with random method and elect 5 primary schools, each of which represents the area of Surabaya Centre, North Surabaya, Surabaya, East, South and West Surabaya. Method of research done by distributing questionnaires to sample student to be filled in the classroom during school hours, accompanied by researchers and classroom teachers. Data analysis using quantitative descriptive with percentage. The result showed that the understanding of elementary school students in the city of Surabaya on the environment is very good. That understanding mostly obtained from parents and teachers. Students' understanding of the environment that obtained from teacher of science, social studies and Indonesian.
\end{abstract}

Keywords: Understanding, elementary school, the concept of environmental

\section{INTRODUCTION}

This study was intentionally conducted to determine how the understanding of elementary school students about the environment. Results of research conducted by the author in Surabaya shows, that the understanding of students, especially elementary schools about the environment turned out to be very good[1]. On the other hand, research done by the Sri Utami from UPI about students' environmental awareness in schools, shows there is less awareness of students on the environment around the school.[2]. Besides that research conducted by KemenLH, 2013, the public awareness about the environment, stated that, "The level of public awareness of the environment is only 57 percent. Deputy Minister of Environment field of community development, Ilyas Asaad said the number indicates that community not behave caring environment in everyday life. Community care for the environment it is 0.57 per cent or 57 per cent, meaning that there is an understanding in the community about the environment but is not as expected, namely to understand and apply the appropriate rules that apply".
According [3], damage the natural environment as a result of natural phenomena or man who later became a serious problem in Indonesia. The destruction of nature is a phenomenon that needs attention in relation to the development of human character for environmental damage caused by the greedy characters, who do not respect the environment, and perhaps also the manner of human character is formed. From various research and opinions of these experts, it turned out just how important an understanding of the environment. Expected with the understanding of the environment will be applied in everyday life, both within the family, school and society in general.

Environmental problems are always of great concern in almost all countries in the world. This is evidenced by the holding of the UN Conference on the Environment in Stockholm in 1972. The conference was notable for the Stockholm Conference which opened on 5 June 1972 therefore agreed on June 5 as World Environment day [4]

The population continues to increase is not offset by an increase of adequate quality of life will cause many problems, especially in developing countries. Development is essentially a process of socio-economic change towards the better. Development activities, the change is expected to occur not only on the physical and institutional, but also changes in the standard of living and the degree of participation of society as a whole in carrying out development in the region. [5]

Environmental problems facing many developing countries posed by poverty[6] thus forcing some voters to deplete the environment. Forests cleared primarily to obtain a settlement and farming. Dirt and trash less taken care resulting in environmental health to be low as a result of pollution, especially by water, air and soil. Thus increasingly apparent that the low income of the population, lack of funds and knowledge, lack of employment opportunities opening up better, a series which has encouraged people to developing countries to exploit natural resources for subsistence. The core problem is how to overcome poverty with development that takes into account environmental considerations.

For Indonesia, this new environmental problems is known about the seventies along with the start of the industrialization program that supports development. Construction of the new factories were placed in major cities 
gradually have immediate consequences in the form of air pollution, water and soil pollution, and declining quality of life, especially from the economically weak.

Indonesia as a country with a large, very feel how heavy pressures due to population problems and environmental degradation. Very severe population problems perceived is its rapid growth and spreading to the whole territory of the Republic of Indonesia is still not evenly distributed. Besides these problems, Indonesia faces urbanization into major cities which generally do not have jobs and ease in achieving adequate living.

Hand, the population growth is very rapid, then the use of natural resources is getting magnified even with knowledge of the population about the management of the environment is still relatively low, due to the problems facing increasing extends even to the further deterioration of environmental quality in the country that we love. The population is much other than as capital construction of the positive side, the negative side is a heavy burden to meet life for food, housing, clothing, education, health and adequate job. If this need is not met no denying humans will make efforts to exploit natural resources on a large scale without considering the consequences. For example, the increasing number of people on the island of Java, the fertile lands as paddy fields, forest, the narrower because used as residential areas, industrial, shopping and others. This indicates that human behavior towards the environment is very cruel, the impact can occur destruction of land, soil erosion, deforestation, causing floods and landslides and other problems either coming from natural or man himself.

According [7], humans interact with their environment. Humans affect their environment and are also influenced by the environment. In an effort to maintain the continuity of life, people trying to take advantage of the natural resources that exist with good management. Humans are very dominant in managing the environment, while human survival depends also on the preservation of the ecosystem[8].

Based on the above we can associate that increase human wellbeing Indonesia should be sure not to damage the natural resources both biotic and abiotic. Plants, animals should be preserved. Thus on the one hand the welfare and quality of life improved, while on the other biotic and abiotic components remain sustainable with conditions suitable and balanced. The living environment is the unity with all things space, power, and the state of the living creatures, including humans and their behavior, affecting the continuity of our lives and welfare of other living creatures (Act 39 of 2009).

In line with the above statement, according by Law No. 23 of 2007 on Environmental Management, section (4) stated that one of the goals of environmental management is embodied Indonesian human as a human environment that has the attitude and acts to protect and nurture the environment. In addition to Article 6 paragraph (1) also states that everyone is obliged to preserve the function of the environment and prevent and mitigate pollution and environmental destruction [9] in the Journal of Basic Education.

Given both the cause and the person in charge of environmental damage and the rescue center point lies in humans, the approach or way out of environmental concerns must come from humans as well. Must be cultivated through education and counseling so that the public is fully aware of what it is for environmental issues and what they mean for himself, his surroundings and his descendants [10].

According to the [11], stated that environmental education bears the characteristics of lifelong education (long life education), both formal (school) or informal (outside school).

Recognizing the importance of education to know about the environment, then the planting concept of the environment should be initiated as early as possible. It was a shared responsibility between parents, schools, communities and government. Thus every Indonesian citizen must understand and realize how important preserving the environment.

\section{Automated assumption generation}

In order to realize these responsibilities in formal education began elementary school (SD) until the College has been included material PLH (Environmental Education), through both monolithic and integrative approach. Especially at the level of Elementary School (SD) PLH given integrative joint fields other studies, namely Science, Social Studies, Civics and PE. The extent to which understanding of the concept of the environment have been understood by elementary school students in the city of Surabaya, which is to be observed. Thus the problem to be observed are: 1) How does an understanding of elementary school students in the city of Surabaya on the environment? 2) Derived from anyone and from any subjects students become acquainted with the environment?. [12]

In this study, we want to know is how much the level of understanding of elementary school students in Surabaya on the environment. Thus, the object being studied at the same time the study population was primary school students in Surabaya. But the number of elementary schools in the city of Surabaya, about 400 elementary school both state and private, making it impossible for researchers to examine everything because of time, money and effort. Without prejudice to the intent and purpose of this study, the researchers conducted the sampling in a sampling of research that is by purposive sampling.

On the basis of high homogeneity and ease of doing research, then the selected SD Negeri, even this may not fully investigate. It is necessary for sampling returned on the basis of high homogeneity then to determine Elementary School into the sample conducted with random (random), the Surabaya region administratively divided into five (5) sections namely Surabaya region Central Region East Surabaya, Surabaya region Northern Territory Surabaya West and South Surabaya region. With equity considerations will be representation from all regions, each administrative region has one primary school in a random way anyway. Thus, there are five (5) samples SD State as the State as the study sample, there is still another consideration that at the primary level there are classes I VI. Accidentally researchers only took a class V as samples with the assumption that the class $\mathrm{V}$ have been taught the environment although implicitly does not stand alone as its own subjects, the class V can already answer the question properly. As for classes I - IV researchers are still not sure if they understand the environment and for class VI investigators not wanting to disturb hour lessons given by a school, given a class VI student must prepare a school final 
exam. With this consideration, the selected class $\mathrm{V}$ as respondents in this study. The division of the selected sample set as follows:

$\begin{array}{llll}\text { SDN Simpang I } & : & 45 & \text { students } \\ \text { SDN Kertajaya VII } & : & 40 & \text { students } \\ \text { SDN Manukan Kulon } & : & 47 & \text { students } \\ \text { SDN South Krembangan: } & 47 & \text { students } \\ \text { SDN Kendangsari III } & : & 46 & \text { students } \\ \text { Total: } & 225 & \text { students }\end{array}$

The research problem, then that variable would like to be detected are: 1) Understanding the fifth-grade elementary school students on the environment, the indicator is: clean and healthy environment; water resources, air and sun; water and air cleanliness; garbage, solid waste, liquid waste and industrial waste. 2) understanding of students about the environment obtained from whom, the indicator is: parents, teachers, other family members, print and electronic media. When the teacher in any subject: Science, Social Studies, Civics, Indonesian, Kertakes or other.

\section{METHOD}

The data collection technique is by distributing questionnaires to all fifth-grade elementary school students were included in the study sample to be filled with the permission of the relevant class teacher. In addition to the questionnaire also uses observations aimed at observing the general implementation of the charging questionnaire on students in each class.

Data analysis using descriptive quantitative criteria percentage $\geq 80 \%=$ very satisfactory, $70 \%-79 \%=$ satisfactory, $60 \%-69 \%=$ satisfactory and $\leq 60 \%=$ unsatisfactory.

\section{Results AND Discussion}

Results of research on the understanding of elementary school students in Surabaya on the environment are presented in Table 1 and Table 2 below:

Table 1. Understanding students of the elementary school class V in the Surabaya city About Environment

No. Students Comprehension about Environment Sum $\begin{array}{llllll} & \text { SM } & \% & \text { M } & \% & \text { CM } \\ \% & \text { TM } & \% & & & \end{array}$

$1 \quad$ Health and Clean Environment $202 \quad 90$ $\begin{array}{llllll}16 & 7 & 7 & 3 & 0 & 0\end{array}$

2 Condition of Health and Clean of Water 191 $\begin{array}{llllll}85 & 21 & 9 & 9 & 4 & 5\end{array}$ 2

3 Condition of Water can to drink $180 \quad 80$ $\begin{array}{llllll}22 & 10 & 14 & 6 & 9 & 4\end{array}$

4 Function of Air and Sunlight $\quad 202 \quad 90$ $\begin{array}{llllll}18 & 8 & 5 & 2 & 0 & 0\end{array}$

$\begin{array}{lllll}5 & \text { Gabage or Refuse 180 } & 80 & 27 & 12\end{array}$ $\begin{array}{llll}16 & 7 & 2 & 1\end{array}$

6 Solid, Liquid and Industry Waste $23 \quad 10$ $\begin{array}{llllll}22 & 10 & 135 & 60 & 45 & 20\end{array}$

Source: primary data, processed
Note :

SM :

M :

$\mathrm{CM}$ :

$\mathrm{TM}$ :

very satisfactory

satisfactory

quite satisfactory

unsatisfactory

From Table 1 above it can be seen that the students understanding of the environment is said to be very satisfactory, it is supported by some indicators that have been investigated turned out to provide very satisfactory results from indicator no. 1 to no. $5(80 \%-90 \%)$ students were very understanding. As for the indicator no. 6 is about solid waste, liquid waste and industrial waste only understood by $10 \%$ of students, so the results are not satisfactory.

Thus the findings obtained that fifth grade elementary school students in the city of Surabaya was very understanding about the environment, meaning the integration of EE materials in elementary schools already can be performed well.

Table 2. Understanding fifth grade elementary students in Surabaya About Environment of Who

No. Students' understanding of the environment that obtained from Sum \%

1 Parents $113 \quad 50$

2 Teachers $90 \quad 40$

3 Other Family members $6 \quad 3$

4 Prnt Media (Magaclzine, News Paper, Book Stories, etc) 52

5 Electronic Media (Radio, Television, Internet, Hp, etc) $11 \quad 5$

Source: primary data, processed

Results of research are presented in Table 1 and Table 2; we can find out how the understanding of elementary school students in the city of Surabaya on the environment. From table 1 can be explained that the understanding of elementary school students about the environment is very good, that reaches each indicator average of $80 \%$, which is detailed from each of the indicators of clean water and a healthy $90 \%$, the requirements of clean water and a healthy $85 \%$, clean potable water to $80 \%$. The understanding by the respondents was obtained from parents (families) by $50 \%$, from the school (teachers of subjects) by $40 \%$. While the subjects most support in understanding the environment according to the respondents are science, social studies and Indonesian. From the results of students' answers these researchers also tried to look at the curriculum of primary school in 2006 and assess any subjects that are likely to be integrated with the material suited PLH. According to research subjects that would make the integration of PLH materials include Science, Social Studies, Civics, Penjaskes (Pendidikan Jasmani dan Kesehatan/Phisycal dan Health Education). In reviewing the 2006 primary school curriculum researchers did not find a match Indonesian lessons when integrated with PLH. But seeing the respondents that the Indonesian subjects included in the lesson to understand the environmental possibilities investigators allegedly lies in the form of readings presented on these subjects. In studying the elementary curriculum in 2004, the researchers found a match for teaching science. 
IPS, Civics, Penjaskes (Pendidikan Jasmani dan Kesehatan/Phisycal dan Health Education). For subjects of science and social studies students' respondents have mentioned, but for the subjects Civics and Penjaskes students' respondents did not mention that the environmental understanding gained from these two subjects. Thus the researchers assume that the Civics teachers and teachers still do not understand PLH Penjaskes (Pendidikan Jasmani dan Kesehatan/Phisycal dan Health Education) are integrated into lessons cultivated[13].

Besides the factor of parents and teachers, factors both print and electronic media played a role, albeit a relatively small amount of 5\% (for print) and $2 \%$ (for electronic media). In table 1 is also available from the answers that students do not understand the true on the definition of solid waste, liquid waste and industrial (10\% obtained from the students' answers of respondents), which has been well understood is rubbish (80\%). From these results the researchers need to note the need for teachers who are included in the above-mentioned subjects are given sufficient solution, especially regarding waste and processing of either solid, liquid and industrial waste as well as the positive and negative impacts posed by these wastes. It is worth highlighting that in this study the question posed to the students not cover all aspects of the environment. This is intentional because consideration of the number of questions when too much will make students reluctant to answer in writing. However, questions have been raised in the questionnaire have been considered representative for elementary students to understand the environment.

In table 2 has served students' understanding of the environment obtained from anyone, can be explained that the resources are used as students to understand the concept of environment, much of the parents $(50 \%)$. This means that the role of parents is very great to instill PLH to children. These findings can be considered for the next policy that the process of learning to understand the environment to children through parents quite effective, just need to think about how to package it to make it easier, for example in the form of textbooks containing material and exercises for the elderly. This is supported by research [9] on the need for the acquisition of supplies to parents either in packs or upgrading of the understanding of the concept of the environment because of the role of parents in transferring PLH more effectively[14].

From table 2 also presented that the role of teachers in the school ranks second. This is when associated with curriculum materials PLH (Pendididikan Lingkungan Hidup/Environment Education) much absorbed in the subsubject of several subjects at each level (SD), (see Table 1). Which proves that teachers teaching science <Social Studies, Civics, Penjaskes (Pendidikan Jasmani dan Kesehatan/Phisycal dan Health Education) not fully understand about the integration PLH (Pendididikan Lingkungan Hidup/Environment Education)with subjects cultivated, if the integration process is already understood by teachers of subjects in question, it is believed that the process of transformation in understanding the environment by elementary students will more quickly and effectively and materials of PLH (Environment Education) for elementary students do not need to do a monolithic approach
Print media such as magazines, newspapers and books with a child turned out to be a role is relatively small $(5 \%)$, this finding little unusual when compared with so many books to read or stories to children about the environment is not yet much to give information, or materials reading selected and read by children is reading material other, more interesting, this is still conjecture researchers. For the role of parents is very important to direct or even choose reading materials for children.

Similarly, the electronic media (TV and Radio) is not much role in providing information to the children about the concept of the environment. From the research results / findings need would receive serious attention in particular to Indonesia to assess more television shows are packed television or radio for children, both regarding material and its delivery hours. From this finding is also the role of parents in the home is needed, especially able to accompany and steer her son and daughter while watching television so that children get the right information.

\section{CONCLUSIONS AND SUGGESTIONS}

Based on the results of research and discussion above it can be concluded:

The elementary school students class V in the Surabaya city was very understanding about the environment. This proves that the briefing materials for elementary PLH has been done mainly on the subjects of science, social studies and Indonesian. An understanding of the environment begins on the role of parents who showed quite effective in instilling environmental concepts to children, new to the role of teachers in the two schools.

To further optimize the retention of material PLH to children, researchers suggest :

To held a training, upgrading or seminars for primary school teachers, especially teachers PPKN, Penjaskes, science, social studies and Indonesian.There should be a television show on the theme of environment and packaged properly so loved by children. The role of parents is very necessary to guide and choose reading materials for children and can assist and give explanations when children watch television.

\section{REFERENCES}

[1] R. Soeryaatmadja, Konsep-konsep Ekologi, Bandung. Bandung: Teknologi Lingkungan ITB, 1987.

[2] W. S. Djamhur, Fisiologi Hewan dan Tumbuhan. Jakarta: Universitas Terbuka, 1985.

[3] K. Kuswara, Pengantar Ekologi. Jakarta: BKKBN, 1983.

[4] O. Soemarwoto, Ekologi Lingkungan Hidup dan Pembangunan. Jakarta: Djambatan, 1987.

[5] S. Bagong, Kemiskinan Dan Kesenjangan Sosial. Surabaya: FISIP Unair, 2009.

[6] S. Soekanto, Sosiologi Suatu Pengantar. Jakarta: CV Rajawali, 1989.

[7] Sujiran, Pendidikan Kependudukan dan Lingkungan Hidup. Depdikbud, 1998.

[8] "Undang-Undang RI Nomor 23 tahun 1997, tentang Pengelolaan Lingkungan Hidup.'

[9] T. Winanti, "Pemahaman Siswa terhadap Konsep Lingkungan Hidup," Pendidik. Dasar, vol. 2, no. 1, 2001.

[10] B. . Marbun, Kota Indonesia Masa Depan, Masalah dan Prospek. Jakarta: Erlangga, 1994.

[11] "Undang-Undang RI No 20 Tahun 2007, tentang Pendidikan Lingkungan Hidup."

[12] "Undang-Undang RI No 23 Tahun 2009, tentang Pokok-pokok ketentuan Pengelolaan Lingkungan Hidup." 
[13] "Undang-Undang No. 4 tahun 1982 tentang Pokok-pokok Ketentuan Pengelolaan Lingkungan Hidup."

[14] P. Dendasurono, Pendidikan Kependudukan dan Lingkungan Hidup, Jakarta: Proyek Peningkatan dan Pengembangan Perguruan Tinggi. Jakarta: IKIP Jakarta, 1985 